\title{
How not to research public spheres: A new "dream of a physics of librarianship"
}

\author{
Comment ne pas faire \\ de la recherche sur les \\ sphères publiques : un \\ nouveau « rêve d'une \\ physique de la \\ bibliothéconomie »
}

\section{John Buschman}

Seton Hall University

\begin{abstract}
Research attention has been focused on the public sphere and librarianship recently, generating disagreement, even controversy. This reflects long-running debates in LIS and related fields. This is not a stale rehash: how we think about the public sphere and libraries is an indicator of libraries in democratic societies and how we position them. A compact account of affinity groupings around this research in LIS will precede an account of the controversy suggesting the question, are there still actually existing public spheres as Habermas deployed the term? The answer clarifies the controversy, and the paper will explore and draw conclusions from it.
\end{abstract}

Keywords: public sphere, Library and Information Science, research, libraries, democracy

Résumé : De nombreuses recherches se sont concentrées sur la sphère publique et la bibliothéconomie, générant de nombreux désaccords récents, voire des controverses. Cette situation reflète bien les débats de longue date en sciences de l'information et dans les domaines connexes. Cette situation ne se répète pas pour rien : la façon dont nous pensons à la sphère publique et aux bibliothèques est un indicateur des bibliothèques dans les sociétés démocratiques et de la façon dont nous les positionnons. Une revue des principales idées autour de ce sujet de recherche en sciences de l'information précédera un compte rendu de la controverse suggérant la question : Y a-t-il encore des sphères publiques existantes au sens que Habermas a utilisé le terme? Cet article tentera d'explorer et de clarifier cette controverse et cherchera à en tirer des conclusions.

Mots clés : sphère publique, bibliothéconomie et sciences de l'information, recherche, bibliothèques, démocratie 


\section{Introduction}

Chances are, if you are reading this you have some idea of why the public sphere is important. Research attention has been focused on the public sphere and librarianship recently, generating some disagreement-even controversy-in the process (e.g., Audunson, et al. 2019a; Buschman 2020; Larsen 2021; Widdersheim and Koizumi 2020). This disagreement reflects long running debates in Library and Information Science (LIS) (e.g., Harris 1986) and related fields (e.g., Brecht 1968; Button and Provenzo 1989) on grounding analyses of complex social processes in empirical methods and theories. This is not to say the recent manifestation of the controversy in LIS is a stale rehash. New investigations produce new insights, and how we think about the public sphere and libraries is an important indicator of how we think about libraries in democratic societies and how we work to position them accordingly. Neither democracies nor libraries in them should be taken as a given these days (Buschman forthcoming). In order to be economical in conveying the disagreements, a compact account of the relationships among the affinity groupings around public sphere research in LIS will be presented, followed by an account of the controversy. This suggests the question, do public spheres still exist in the broad sense that Habermas $(1974,49)$ deployed the term ( $^{1}$ The answer clarifies the controversy, and the remainder of the paper will explore and draw conclusions from it.

\section{The affinity groupings ${ }^{2}$ and the disagreement}

It is necessary to begin with caveats. First, the following sketches are not meant to be comprehensive-neither bibliographically nor in the characterization of the research of each grouping. Second, if there is a wish to investigate that research further it is assumed that the reader will refer to the bibliographies in the works cited for the groupings. Third, the groupings reflect affinities, not a lockstep of agreement on the public sphere. Fourth, the tongue-in-cheek-named groupings do not have perfectly clear lines of demarcation; authors and ideas appear in other groupings and in citations. The goal is to present broad affinities and common assumptions that drive research in each area to highlight the relative positioning of each, to roughly map the disagreements and to frame the high-level issue at hand.

\section{The Cultivators}

The first affinity grouping looked at contemporary large-scale social changes challenging public institutions and public purposes (most recently under neoliberalism) and deployed the public sphere concept to cultivate LIS institutions and practices by situating and explaining the social and democratic goods they foster and/or instantiate

\footnotetext{
${ }^{1}$ See the section on "The key question" for his basic deployment of the term.

${ }^{2}$ As a category, affinity grouping 1, The Cultivators, was drawn from Widdersheim's (2017) and Widdersheim and Koizumi's $(2016,594-596)$ literature reviews/overviews, as well as Audunson, et al. (2019a, 776-777, 781). Affinity grouping 2, The Social Capitalists, was drawn from literature reviews in Audunson, et al. (2019a, passim) and Vărheim, Skare and Lenstra (2019, 96-97). Affinity grouping 3, The Scientists, was identified by Audunson, et al. $(2019 a, 778,785)$ and is arguably self-defined by its authors.
} 
(see the bibliographies in Audunson, et al. 2019a; Widdersheim 2017). The vision of libraries "democratically connected to its community...in light of democratic public purposes and the need to provide alternatives and alternative spaces in a culture dominated by information capitalism and media image and spectacle" is core to the Cultivators (Buschman 2003, 180). The questions they broadly seek to answer are: 1 ) is the public sphere concept contemporary, flexible, pluralistic and explanatory of what libraries do and, 2) do library fostered forms of interchange between people, discourses, and democratic society that have public sphere-like qualities occur? The most recent contribution of this grouping is in attempts to discuss the public sphere and libraries within a deeper democratic theory context (e.g., Buschman forthcoming; 2012; 2018).

\section{The Social Capitalists}

The second grouping arose from work primarily centered in Scandinavia and Northern Europe that initially focused on libraries in relation to social capital (e.g., Vårheim 2007; 2008). As such, this grouping consciously serves as a bridge from questions of the values of libraries (including fostering social capital), to how society does and does not value libraries, to social capital and its relationship to libraries and then the public sphere (e.g., Kajberg 2013; Huysmans and Oomes 2013; Audunson et al. 2019a; 2019b; Varheim, Skare and Lenstra 2019). As such, the questions the Social Capitalists broadly seek to answer are: 1 ) how is social capital generated in libraries and how is this manifested empirically, and 2) can this evidence be brought to bear to justify ${ }^{3}$ and position libraries? (Vårheim 2007, 425-426) This affinity grouping attempts to generate empirical evidence-"research on libraries and social capital stands out as a strand of research basing itself on empirical research" (Audunson et al. 2019a, 781) following the original work in political theory that documents and measures social capital (see Vårheim 2008; Johnson 2015). The Social Capitalist's categories of public sphere analysis and investigation still display those roots.

\section{The Scientists}

Audunson et al. (2019a, 778, 785) calls the work of the authors of this group "profound," characterizing the nature of prior public sphere LIS scholarship as merely normative and non-empirical. The Scientists seek to answer the clarion call for evidence issued by the Social Capitalists: "More empirical studies are needed because research about the public sphere requires a mix of theory, conceptual analysis, and empirical evidence" (Widdersheim and Koizumi 2017). They look for proof of the existence and operation of the public sphere in libraries as a direct and repeated critique of what they claim is the misappropriated and vague concept deployed by the Cultivators (Widdersheim 2017; Buschman 2020; Larsen 2021). As such, the questions the Scientists seek to answer are: 1 ) if "Habermas did not operationalize the elements in...models," how then to "bridge the gap between abstract ideas...and empirical evidence drawn from library cases" (Widdersheim and Koizumi 2020, 620), and 2) what

\footnotetext{
3 The unfortunate term the Social Capitalists later used, like the Grouping 3 authors, is "legitimation"
} (Buschman 2020, 775-776). 
are the theoretical-methodological "crosswalks" (Widdersheim 2015, 243) that "operationalizes variables to create public sphere models" (Widdersheim and Koizumi $2020,620)$ ? This work seeks to fill that gap and correct the purported deficiencies to explain the workings and development of libraries and the public sphere in them.

\section{The disagreement}

The first element in our disagreement/controversy has been sketched. In taking up the call of the Social Capitalists for empirical evidence concerning the public sphere and libraries, the Scientists turned that effort into a critique of the Cultivators' public sphere literature as "originalist" (Widdersheim and Koizumi 2020). By this they mean the concept as deployed displays "problems of anachronism and anatopism...and because the problems have been overlooked, no solutions yet exist" (Widdersheim 2017). In order to produce data, the Scientists proposed an ontology to "specif[y] basic categories of experience and define...how they are organized," thus requiring the crosswalk of other theoretical concepts to re-articulate a theory of the public sphere (Widdersheim and Koizumi 2017). That schematized it into layers, communication channels, signals, audiences, etc. (Widdersheim 2017; Buschman 2020). It could then be coded and mapped onto practices and discourses in libraries that demonstrated evidence of the public sphere schema itself, correcting the purported over-normative and non-empirical public sphere research in prior LIS. The issues, groupings, and controversy boils down to Buschman vs. Widdersheim and Koizumi: critiquing the Scientists in turn is "not a pedantic exercise in simply noting where the authors are coloring outside of proper lines drawn by Habermas and his interlocutors. They have taken a cultural concept-the public sphere-and operationalized it in a model" that thinned out, scientized and distorted the concept beyond recognition after relying on Habermas heavily to ground and justify the importance of their work (Buschman 2020, 776). The Scientists' efforts produced copious and complex charts, diagrams, and maps (e.g., Widdersheim and Koizumi 2017; 2020) and some startling empirical "results" in the form of "dimensions and sub-dimensions of the public sphere in public libraries" (Widdersheim and Koizumi 2016, 601) that included distribution of funds, donations, focus groups, founding a library shop, and reporting sales totals, and libraries deploying cops for "teenagers roaming the streets...intent on doing damage or creating disturbances" (Widdersheim and Koizumi 2015, 9). These results were instead said to be "more akin to strategic planning (or group therapy)" than recognizable public spheres (Buschman 2020, 772-773). A gentler view concluded that the concept changed enough to be a new theory (Larsen 2021, 252).

\section{The key question}

This controversy spans theories and research across dozens of articles as well as books and conference papers, bringing in work from related fields. While there are many moving parts, the key point is the charge of originalism, suggesting an essential 
question: are there still actually existing ${ }^{4}$ public spheres in a recognizable sense that Habermas deploys the term? As the Scientists frame it, "in its most basic and generalised sense, the political public sphere expresses a reciprocal speaker-audience relationship" (Widdersheim and Koizumi 2017) that, while deploying Habermas' vocabulary, calls forth other theoretical categories to expand, identify, and situate the public sphere aspects in libraries and analyze the empirical evidence that emerges as a result. In turn, the "basic and generalised sense" of the public sphere for Habermas $(1974,49)$ is as "a realm of our social life in which something approaching public opinion can be formed." Access is open, and "a portion of the public sphere comes into being in every conversation in which private individuals assemble to form a public body.... ${ }^{5}$ Citizens behave as a public body when they confer...about matters of general interest [and] when the exercise of political control is effectively subordinated to the democratic demand that information be accessible to the public."

There are three points to be made about his basic and generalised public sphere concept. First, no one has "to don a powdered wig to take the central ideas" of the public sphere and democracy seriously (Peters 1993, 544)-least of all Habermas who long ago acknowledged a "pluralization of the public sphere" $(1992,426)$. Public spheres-even in this basic sense-now include counterpublics, new publics (e.g., ethnic groups), diasporic publics, and deliberative publics generated by women, countercultures, racial minorities, LGBTQ people and groups organized around issues like the environment, civil rights, or other matters of general interest (Fraser 1992, 123; 2009; Benhabib 1998, 97). Second, from the beginning there has never been a shortage of interlocutors and debate around Habermas' public sphere. For almost six decades "even when Habermas has been contradicted, it is usually within the framework of his theory" (Hohendahl 1979, 89), and adaptations have long been welcomed and absorbed in Habermasian public sphere theory. This controversy, after all, is over the public sphere and its relationship to libraries-an extension Habermas did not contemplate. ${ }^{6}$ Other adaptations of Habermas' public sphere concept include women's public spheres in nineteenth century America (Ryan 1998), ideas of solidarity (Larsen 2021, 254), "some common space of discussion...linking people who may never meet" (Taylor 1993, 226), simply as a "set of activities that constitutes a democratic society's self-reflection and self-governance" (Schudson 1994, 530), or public spheres as amplifying resistance to state domination (Hove 2009, 32-33). Revision is not wholesale rewriting of the theory. Third, the public sphere is political and public. Politics is the contest for power (Blokker 2018), but the political involves "our relationship with collectivities" (Freeden 2013, 5), normative questions, particularly about freedom (Heller 1991, 341; Warren 1999, 209), and negotiating dissent (Freeden 2005, 127). In turn collectivities are by

\footnotetext{
${ }^{4}$ This phrase is taken from Fraser (1992), who herself critiques, adapts, and otherwise engages Habermas' concepts.

${ }^{5}$ That is, he contrasts this behavior with private business or professional transactions and also with those in state bureaucracies.

${ }^{6}$ He did not so much "overlook" libraries (Widdersheim 2017) but rather his project was much broader, only touching on education occasionally but productively framing issues that concerned schools, universities, and libraries (Buschman 2014).
} 
definition public. Engagement creates public spaces and "moments of commonality when...public deliberations....promote or protect the well-being of the collectivity" (Wolin 1996, 31) and "whatever leaves this domain ceases to be political" (Heller 1991, 330, 340). Habermas has repeatedly, explicitly and implicitly reaffirmed these points at varying levels of scale in recent writings and remarks (e.g., 2006; 2020; in Calliess, et al. 2011).

\section{Are there still Habermasian public spheres?}

One way of parsing the question and the LIS controversy at hand is to see if there is evidence of actually existing Habermasian public spheres. If there is evidence, then that calls for a reassessment of the basic research assumptions of the Scientists. The answer is a surprisingly easy yes: examples are not difficult to find. This is not an exhaustive accounting of them, but they are frequently discussed as public spheres in both the scholarly and popular literature. Again, we are speaking about the "basic and generalised sense" of public spheres that Habermas long ago agreed was pluralized across locations, identities, and issues here, not an exercise in parsing criteria of a scientific-like definition. A few examples are as follows.

\section{The Euromaidan, 2014}

Also known as Ukraine's Revolution of Dignity, the Euromaidan (or the Maidan) came out of the historical-cultural context of Ukraine, Russia/the Soviet Union, World War II, and Eastern Europe via a complex set of political betrayals, reversals, and violence (Shore 2017, all page numbers in this paragraph are from this volume). The President "had broken an unspoken social contract:...students in Kiev had been beaten" protesting his last-minute refusal to sign a trade agreement with the European Union, resulting in "spontaneous self-organization...[of] impassioned protest against brutality, corruption, and rule by gangsters...a revolt against...arbitrariness and tyranny" that occupied its Independence Square (Maidan) for months, day and night, in freezing weather, persisting despite Russian infiltration, media propaganda, and violence intended to confuse the issues and stir up homophobia, anti-Semitism, and a false antifascism (39-45). The heart of the protests that followed took place in Kiev's Maidan but was imitated in Maidans across Ukraine. "People came to the Maidan to see what was there and ended up staying...akin to Noah's Ark: 'it took two of every kind' [and it] was 'maximally open'...and tolerated very different programs," peaceful, cooperative, and well-fed (51-53). "[T]he borders that normally existed between people dissolved; it became very easy to talk to strangers...a 'laboratory of the social contract"' (40) in pursuit of "a democratic society composed of people who had made common choices about what they wanted and what they valued" (139). This vision was, in parts, consciously built on ideas of the public sphere, free exchange, and civil rights (191).

\section{The Arab Spring, 2011}

A "modern mass democratic movement...emerged in the Arab world" in the spring of 2011 across many different countries and capitals in a complex set of situations cutting across differing national political contexts and Muslim denominations, 
but in common "struggl[e] for democratic freedoms, a free public sphere, and joining the contemporary world after decades of lies, isolation, and deception" (Benhabib 2011). It was a movement consciously meant to break the hold of national media on discussion and agenda-setting, restrictions on women, and to free interchange and discourse; in a reversal of influence, the Arab Spring protesters found common cause at the time with workers' issues in Wisconsin and were later imitated by activists in Oklahoma, the Occupy movement, and striking teachers in West Virginia (Clarke and Koçak 2019; Coll 2011; Benhabib 2011; Wessler 2018, 111, 142).

\section{The library closure protests in London, 2011}

A late 2010 council proposal in the London borough of Brent to close half of its libraries generated significant protest (overshadowed at the time in media coverage by the Arab Spring). The protests over the library closures brought "forth public spheres intent upon resisting the changes" (Ingraham 2015, 156, page numbers in this paragraph are from this article). The council, despite this feedback during the public comment period, persisted in passing the closure plan in spring 2011. People pushed back: "Three Brent residents-backed by thousands of supporters-filed" a lawsuit challenging the decision, the process and its premises, garnering considerable press coverage. "With rampant library closures imminent throughout England, these debates were very much national news" $(160,158-161)$. Such incidents are not isolated. As of this writing a web search of "protesting library cuts" produces many results from many locations (https://tinyurl.com/LibrariesCut).

\section{Post-Katrina New Orleans, 2005-2010}

After the devastation of Hurricane Katrina, there were plans among the city's elite for a "bigger and better" New Orleans built on a "blank slate" turning public housing into expensive condos, increasing the footprint of the casinos, razing "generations-old neighborhoods [as] 'pockets of poverty"' to make way for other developments "with the people of New Orleans dispersed" to build an "Afro-Caribbean Paris" (all quotes from Baum 2010). A watchdog group member at the time saw a developer's map with the whole thing planned, but

in church basements and coffee shops, New Orleanians met over and over, plotting to fend off plans that clashed with their neighborhoods' identities and their city's sense of self. At one gathering in a... church...a woman [said] with tears in her eyes that 'People like to talk about hard facts but...these new buildings mean absolutely nothing to us. The social networks mean everything.' [P]eople [from] all over the city drove the barbarians from the gate[:] meetings and marches; T-shirts, fliers and spray-paint on sodden houses...and occasional hollering at council members and planning commissioners got the message across." The plans faded in the face of sustained resistance, "and the city grew back organically, street by street, neighborhood by neighborhood, the way its people wanted.

Even in these brief accounts themes of resistance to illegitimate authority (dissent), discourse, public gathering, solidarity, democratic values, and freedom-that 
is, of the political and public character of Habermasian public spheres-appear consistently throughout. There are other examples. Brazilian scholars have reexamined the study of their country's history and found, at periods, examples of new publics and subaltern public spheres in that scholarship, identifying similar studies for Russia, South Korea, and throughout Latin America (Garcia et al. 2018). Contemporary scholars and journalists point to public spheres arising from the Black Lives Matter movement and the Women's March among others to resist the authoritarian, racist, and misogynistic policies and rhetoric of the 2017-2021 US Presidential administration (Randeria and Snyder 2020; Olmstead 2019). Does that mean public spheres are everywhere all the time? Probably not. They are-and always were-unusual, a response to serious disruption (Warren 1995, 171). It is also worth noting that public spheres are not always successful: the London lawsuit failed and the first 2004-2005 "Orange" revolution in Ukraine failed because of a lack of follow through (Shore 2017). But they appear. Public spheres are not anachronistic and anatopic in the real world, and therefore it is valid to analyze libraries' relationship to the phenomena. To argue against the evidence for Habermas' basic and generalised sense of public spheres, the Scientists must make the argument that anachronism and anatopism are essential to the meaning of the public sphere, and that it is distorted thus by eliminating the original bourgeois aspect, coffee houses, the early print press, and confining women to the private (household) sphere, or that pluralistic, inclusive basic Habermasian public spheres are somehow not really public spheres, or that the examples do not fit his basic sense.

\section{A new "dream of a physics of librarianship"}

If, in a basic and generalised sense, public spheres still appear and exist, then what exactly are the Scientists doing? The crosswalk concept-essentially a mashup of technical-managerial concepts with public sphere categories-has resulted in a Frankentheory. To update an earlier characterization, the Scientists are constructing a new "dream of a physics of librarianship" (Harris 1986, 217). Harris (among other scholars) was writing of the (successful, he contends) three decade "attempt to make librarianship a science" in the early twentieth century: that "quantitative measurement and numeration are [essential], complex phenomena [are] best understood by reducing them to their essential elements [and] the library...[is] viewed as a complex of facts governed by general laws" (1986, 218-219). This precisely echoes Habermas' own critical view of such efforts as reviewed in the LIS literature (Benoit 2002, 459). Rather than deploying the public sphere as an analytic category (Dahlgren 1991, 2) the Scientists are repeating some history in constructing a scientific account of libraries and following another similar pattern in political science concerning whether political theory must be "done in line with scientific method in the strict sense" (Brecht 1968, 308). The clarion call is for more empirical work in this effort, but what constitutes empirical study and evidence in LIS and how to gather, produce, and analyze it? Hjørland $(2005,149)$ observes that "nobody argues against empirical studies. The question is how best to do" them. So framed, the broad characterizations of the Cultivators' literature are simply inaccurate. Two instances illustrate. Buschman (2003), in advancing his argument on 
dismantling the public sphere, pulls together spending data, managerialist statements in the LIS literature, and examples of library designs that reorient the purpose of libraries. The edition of the McCook volume (2004) cited as part of the survey of inadequate LIS literature on the public sphere (Widdersheim and Koizumi 2017) speaks of public spheres interweaving with cultural heritage, education, and community, citing library publications, programs, and events in the account. In other words, both cite and analyze empirical evidence; much of the LIS public sphere literature does so.

Constructing a scientific picture of the public sphere by crosswalking the categories from technical communications schema, the Scientist's results "collapse[s] discourse or politics into social organization" (Calhoun 1993, 269) obviating any sense of actually existing public spheres. An earlier effort by H. T. Wilson (1985) entitled Political Management: Redefining the Public Sphere was more forthright, stating clearly the goal of the "possibility and desirability of a practical science of politics" applied to institutions (v). ${ }^{7}$ Intentional or not, this is what the Scientists are doing for libraries. Two key moves signal this. First, a portion of the titles of two papers tells the tale: "a search for the public sphere in public libraries" (Widdersheim 2017) and "a model of the public sphere in public libraries" (Widdersheim and Koizumi 2017). As noted, public spheres take place in public, are political and involve dispute, democracy, and varieties of people and discourse; actually existing examples illustrated this. Ingraham (2015, 156) makes the point that even public spheres coalescing around libraries themse/ves are external to it: they are "public spheres attending to public library issues" in public, not in the library itself. By structuring the inquiry this way, the Scientists guaranteed discovery of a "gap" "requiring" new categories to rearticulate and redefine the public sphere in libraries.

The other related Scientist move is defining the public sphere "in its most basic and generalized sense" as a "reciprocal speaker-audience relationship" (Widdersheim and Koizumi 2017). This is the heart of the model of "signal, transmitter/modulator, receiver/demodulator, medium/channel, and message" crosswalked into public sphere vocabulary to transform the categories themselves to find empirical evidence of the public sphere in libraries (Widdersheim and Koizumi 2015, 2-3). From there moves toward other technicist and managerialist models become easier. ${ }^{8}$ Given this framing, the Scientists understandably find little explanation in the LIS literature of the historical development of libraries either as public spheres or the public sphere in libraries. Meanwhile, scholars identified "lending libraries" among other institutions as part of "an emergent infrastructure" of it along with new public spaces in the eighteenth and nineteenth centuries (Johnson 2001, 219). Libraries developed in multiple ways, and what that has to do with public spheres is a complex question. But when actually

\footnotetext{
7 Indeed, Habermas appears only once in the book approximately two-thirds the way through (Charles de Gaulle also appears once, Aristotle 51 times).

${ }^{8}$ In this the Scientists are replaying another bit of early history of education in its quest for scientific management of complex social institutions (schools and classrooms), drawing Paolo Freire's critique of the "banking" concept of education as the "pouring of contents into students heads" (in Stone 2011, 68), remindful of the speaker-audience model of the public sphere.
} 
existing public spheres are not defined out of existence the outline is not entirely obscure:

- $\quad$ "During the first half of the nineteenth century, institutions other than schools played increasingly important roles in education...It was not until the last quarter of the...century that successful attempts were undertaken to organize the library movement on a national basis" (Button and Provenzo 1989, 162-163).

- Libraries were among the institutions with public and political support to help the young: "public schools, benevolent societies, rehabilitative prisons, reformatories, and, for the truly unfortunate, insane asylums" (Wilentz 2005, 489).

- The sunny view was that "whatever the particular reasons for their creation, public libraries...enabled readers to make whatever use they wanted of collections, which became increasingly broad-minded and more accessible" (Dain 1996, 62).

- The less sanguine view was that they were instruments of control, particularly for the poor and immigrants (Harris 1986).

- Wiegand (2015; 1999) synthesizes these perspectives: both happened. That is, the profession produced an institution that excluded and tried to control, but also fostered connections among discourses and among publics resisting those strictures, fostering public spheres at times throughout.

The Scientists framed their search such that this discourse on library development defined public spheres out of existence thereby producing an anachronistic and anatopic LIS literature.

Last, they trust evidence too much. Even the established work on social capital in democratic theory is subject to fierce debate over the sources and meaning of the data, how much there is of it, and the conclusions drawn (Stolle 2007, 660-664). The Scientists cite a summation of deliberative qualities of media as an example of "how work in other fields measures deliberativeness in public sphere media such as news shows, newspapers, Twitter, and blogs" (Widdersheim and Koizumi 2020, 620). News coverage and current events have been saturated with information on the recent destructive role of Twitter, Facebook, and Fox News (mapping three media categories) in Russian interference, fake news, disinformation, racism, and authoritarianism among others (Draper 2020). Media "deliberativeness" is far from settled. For example, social media seem to help democratic protests organize, but authorities respond to co-opt or control them (Clarke and Koçak 2019; Coll 2011; Garnett 2019), and the January 6, 2021 Insurrection to overturn a democratic election was itself coordinated on social media (Frenkel 2021). "This is a world where warlords...promote themselves on Instagram and Twitter" after all (Shore 2017, xvi). Using social media to coordinate timing and movements, document repressive violence and protest are important, but do not in themselves constitute public spheres-unless defined as a speaker-audience relationship. If so, the January 6, 2021 Insurrection constituted a democratic public sphere. But publics are "something other than merely media audiences" (Dahlgren 2006,274 ) and there are concerns over "modern media's contribution to the decay of the public sphere; in fact, such has been the basic message from critical media research 
over the years" (Dahlgren 1991, 11). ${ }^{9}$ Scholars open to the media-public sphere nexus are much more circumspect (e.g., Garnham 2001; Butsch 2011; Lunt and Livingstone 2013; Fuchs 2014). Further, these media channels quickly come to reflect corporate ownership oriented to surveillance and behavior-based marketing (Fuchs 2014; Doyle and Veranas 2014, 211-217; Zuboff 2016). ${ }^{10}$

In sum, the Scientists' work may accomplish some things, but this is an example of how not to research public spheres, producing an account of libraries that bears no resemblance to actually-existing ones. The search for a scientific status maps prior attempts in other fields, and a too-optimistic faith in evidence that is essentially contested in its meaning. They mistake the pieces for the pie: Habermas' theory has been modified and contested over the years, but it is still recognizable and viable as a description - an analytic category-of real events in democratic life. Those modifications enhance his model. The Scientists crosswalk it into a Frankentheory.

\section{Why it matters}

The field of education has reasonably good practices, techniques, and research about them, but what purposes do they serve? What are they for (Wingo 1974, 345)? The same question goes for libraries: what are they for? How we shape and research libraries and public spheres always contains implicit assumptions. Adapting a phrase Wiegand $(2015,2)$ has adopted, the Scientists assume a public-sphere-in-the-life-ofthe-library approach that tends to abjure such broader questions. Following Wiegand, this is flipped. The library-in-the-life-of-the-public-sphere raises salient questions of libraries and their role in democratic societies: what are they for and what do they do? That is too much to be accomplished here (see Buschman forthcoming), but a recent article (Söderholm and Nolin 2015) points to a productive start to guide research:

- The social approach is that "in which the library is a locus and enabler...[and] develop[s] (infra)structure" (244). The societal approach emphasizes "popular education...[and] the digital extension of libraries...spanning...back-end collection management to front-end e-reading and social media" (244).

- The move is broadly "from the building of society to the building of relations" (244) - we privilege the social over the societal. They "us[e] the notion of community as a merger" of the approaches (245). This allows both the "library's signature offering: a place that lets community members borrow things" (249), and a focus on the library as place and the digital extension of services and access (245).

- Tool libraries are illustrative of the combined assumptions behind this approach. They posit that communities consist of people who do things and need to

\footnotetext{
9 See for example Slack (1984), Douglas and Guback (1984), Lyon (1986), Peters (1987; 1988), Rosen (1992), various summaries in Webster (2006) and Fuchs (2014).

${ }^{10}$ And this is before we get to the underlying effects of technology on human association, social space, meaning-making, learning, and development (e.g., Rasch 2020; Barba-Kay 2019; Messer-Kruse 2019; Miller 2012).
} 
temporarily borrow stuff for those purposes from a place that stores and makes them accessible, calling into question how tools are organized for access and having immediate implications for on-site collections, services, and spaces as well as infrastructure, outreach, and organization (251-254). The "space and place of...libraries needs to be investigated as more than a confluence of people in a material vacuum." A library without an actual collection in a space, and working to connect both to its community, "would be a dubious library indeed; the two [perspectives] cannot be properly separated in any meaningful way" (257).

- This framing suggests that the question "is not how people should be categorized...as user, customer, reader, consumer, citizen, community member, borrower, patron....but why such an institution should be working with people at all." The transition from the societal to the social perspective "has us constantly trying to fill the gap, which is the...library mission, with meaning. An obvious starting point is the democracy angle" (255).

Rather than a scientized redefinition of public sphere categories in order to find them in libraries, this perspective looks at the library in the life of the person, the desires of her community, and what stuff people actually need and do. Community here means both local and as situated in the broader context of democratic society. For some time, libraries operated (and have been researched) under a settled set of assumptions in democracies: that apolitical citizens are a permanent condition reflecting satisfaction with the system; that is not a problem; there is wide agreement on democratic norms among leaders; it did not matter if there was not agreement among people; and, there is a high value on stability (Walker 1970, 246-247). There is not much need for evanescent public spheres there, but this has not characterized democracies for some time now. Libraries and LIS research can no longer ignore their part in democratic society, including scientized public spheres premised on a speaker-audience model with attendant assumptions and consequences.

\section{About the author}

John Buschman is dean of University Libraries at Seton Hall University. Buschman is author of Dismantling the Public Sphere: Situating and Sustaining Libraries in the Age of the New Public Philosophy (2003). His most recent book is Libraries, Classrooms and the Interests of Democracy: Marking the Limits of Neoliberalism (2012), and he is the author of many articles in Library Quarterly, Journal of Documentation, and other leading journals. He holds an M.L.S. from Ball State University, an M.A. in American Studies from St. Joseph's University, and a Doctor of Liberal Studies from Georgetown University. Email: john.buschman@shu.edu

\section{References}

Audunson, Ragnar, Svanhild Aabø, Roger Blomgren, Sunniva Evjen, Henrik Jochumsen, Håkon Larsen, Casper Hvenegaard Rasmussen, Andreas Vårheim, Jamie Johnston, and Masanori Koizumi. 2019a. "Public Libraries as an Infrastructure for 
a Sustainable Public Sphere: A Comprehensive Review of Research." Journal of Documentation 75 (4): 773-90. https://doi.org/10.1108/JD-10-2018-0157.

Audunson, Ragnar, Svanhild Aabø, Roger Blomgren, Hans-Christoph Hobohm, Henrik Jochumsen, Mahmood Khosrowjerdi, Rudolf Mumenthaler, Karsten Schuldt, Casper Hvengarrd Rasmussen, Kerstin Rydbeck, Máté Tóth, and Andreas Vårheim. 2019b. "Public Libraries as Public Sphere Institutions: A Comparative Study of Perceptions of the Public Library's Role in Six European Countries." Journal of Documentation 75 (6): 1396-1415. https://doi.org/10.1108/JD-022019-0015.

Barba-Kay, Antón. 2019. "The Sound of My Own Voice." Eurozine, January 31, 2019. https://www.eurozine.com/the-sound-of-my-own-voice/.

Baum, Dan. 2010. "Five Years after Hurricane Katrina, How New Orleans Saved Its Soul." Washington Post, August 22, 2010. https://www.washingtonpost.com/wpdyn/content/article/2010/08/20/AR2010082002125.html.

Benhabib, Seyla. 1998. "Models of Public Space: Hannah Arendt, the Liberal Tradition, and Jürgen Habermas." In Feminism, the Public and the Private, edited by Joan B. Landes, 65-99. New York: Oxford University Press.

Benhabib, Seyla. 2011. "The Arab Spring." Eurozine, May 10, 2011. https://www.eurozine.com/the-arab-spring-religion-revolution-and-the-publicsphere/.

Benoit, Gerald. 2002. "Toward a Critical Theoretic Perspective in Information Systems." Library Quarterly 72 (4): 441-471. https://doi.org/10.1086/lq.72.4.40039792.

Blokker, Paul. 2018. "Democracy and Democratization: Theory and Research." In The Sage Handbook of Political Sociology, edited by William Outhwaite and Stephen P. Turner, 622-636. Los Angeles: Sage.

Brecht, Arnold. 1968. "Political Theory: Approaches." In International Encyclopedia of the Social Sciences, Vol. 12, edited by David L. Sills, 307-318. New York: Macmillan.

Buschman, John. 2003. Dismantling the Public Sphere: Situating and Sustaining Librarianship in the Age of the New Public Philosophy. Santa Barbara, CA: Libraries Unlimited.

Buschman, John. 2012. Libraries, Classrooms, and the Interests of Democracy: Marking the Limits of Neoliberalism. Lanham, MD: Scarecrow Press.

Buschman, John. 2014. "Habermas and Intellectual Freedom: Three Paths." In The Library Juice Press Handbook of Intellectual Freedom: Concepts, Cases, and Theories, edited by Mark Alfino and Laura Koltutsky, 71-89. Sacramento, CA: Library Juice Press.

Buschman, John. 2018. "On Democracy and Libraries." Library Quarterly 88 (1): 23-40. https://doi.org/10.1086/694871.

Buschman, John. 2020. "The Public Sphere without Democracy: Some Recent

Work in LIS." Journal of Documentation 76 (3): 769-783.

https://doi.org/10.1108/JD-06-2019-0115.

Buschman, John. Forthcoming. "Actually-Existing Democracy and Libraries: A Mapping 
Exercise." In Libraries and the Global Retreat of Democracy: Confronting Polarization, Misinformation, and Suppression, edited by Natalie Greene Taylor, Karen Kettnich, Ursula Gorham, and Paul Jaeger. Bingley, UK: Emerald.

Butsch, Richard. 2011. "Audiences and Publics, Media and Public Spheres." In Handbook of Media Audiences, edited by Virginia Nightingale, 149-158. Malden, MA: Blackwell.

Button, H. Warren and Eugene F. Provenzo. 1989. History of Education and Culture in America. Englewood Cliffs, NJ: Prentice Hall.

Calhoun, Craig. 1993. "Civil Society and the Public Sphere." Public Culture 5 (2): 267280.

Calliess, Christian, Henrik Enderlien, Karsten Fisher, Ulrike Guérot, and Jürgen Habermas. 2011. "Europe and the New 'German Question.'" Eurozine, August 26, 2011. https://www.eurozine.com/europe-and-the-new-german-question/.

Clarke, Killian, and Korhan Koçak. 2019. "Eight Years After Egypt's Revolution, Here's What We've Learned About Social Media and Protest." Washington Post, January 25. https://www.washingtonpost.com/news/monkey-cage/wp/2019/01/25/eightyears-after-egypts-revolution-heres-what-weve-learned-about-social-media-andprotest/.

Coll, Steve. 2011. "The Internet: For Better or for Worse." The New York Review of Books, April 7, 2011: 20-22.

Dahlgren, Peter. 1991. "Introduction." In Communication and Citizenship: Journalism and the Public Sphere, edited by Peter Dahlgren and Colin Sparks, 1-23. New York: Routledge.

Dahlgren, Peter. 2006. "Doing Citizenship: The Cultural Origin of Civic Agency in the Public Sphere." European Journal of Cultural Studies 9 (3): 267-286. https://doi.org/10.1177/1367549406066073.

Dain, Phyllis. 1996. "American Public Libraries and the Third Sector: Historical Reflections and Implications." Libraries \& Culture 31 (1): 56-84.

Douglas, Sarah, and Thomas Guback. 1984. "Production and Technology in the Communication/Information Revolution." Media, Culture \& Society 6 (3): 233245.

Doyle, Tony, and Judy Veranas. 2014. "Public Anonymity and the Connected World." Ethics and Information Technology, 16 (3): 207-218. https://doi.org/10.1007/s10676-014-9346-5.

Draper, Robert. 2020. "Unwanted Truths: Inside Trump's Battles with U.S. Intelligence Agencies." New York Times Magazine. August 8, 2020. https://www.nytimes.com/2020/08/08/magazine/us-russia-intelligence.html.

Fraser, Nancy. 1992. "Rethinking the Public Sphere: A Contribution to the Critique of Actually Existing Democracy." In Habermas and the Public Sphere, edited by Craig J. Calhoun, 109-142. Cambridge, MA: MIT Press.

Fraser, Nancy. 2009. "Global Justice and the Renewal of Critical Theory." Eurozine, April 21, 2009. https://www.eurozine.com/global-justice-and-the-renewal-of-criticaltheory/.

Freeden, Michael. 2005. "What Should the 'Political' in Political Theory Explore?" Journal 
of Political Philosophy 13 (2): 113-34. https://doi.org/10.1111/j.14679760.2005.00216.x.

Freeden, Michael. 2013. The Political Theory of Political Thinking. New York: Oxford University Press.

Frenkel, Sheera. 2021. "The Storming of Capitol Hill Was Organized on Social Media." New York Times, January 6, 2021.

https://www.nytimes.com/2021/01/06/us/politics/protesters-storm-capitol-hillbuilding.html.

Fuchs, Christian. 2014. "Social Media and the Public Sphere." TripleC: Communication, Capitalism \& Critique 12 (1): 57-101. https://doi.org/10.31269/triplec.v12i1.552.

Garcia, André Spuri, José Roberto Pereira, Valderí de Castro Alcântara' and Elaine Santos Teixeira Cruz. 2018. "Understanding the Concept of Public Sphere in Social Management: Ideas for an Empirical-Descriptive and Normative Reconstruction." Cadernos EBAPE.BR, 16 (2). http://dx.doi.org/10.1590/1679-395160265.

Garnett, Simon. 2019. "Internet Technologies and Democracy: Editorial." Eurozine, January 31, 2019. https://www.eurozine.com/internet-technologies-democracyeditorial/.

Garnham, Nicholas. 2001. "Public Sphere and the Media." In International Encyclopedia of the Social and Behavioral Sciences, edited by Neil Smelser and Paul Baltes, 12585-12590. New York: Elsevier.

Habermas, Jürgen. 1974. "The Public Sphere: An Encyclopedia Article (1964)." New German Critique, no. 3 (October): 49-55. https://doi.org/10.2307/487737.

Habermas, Jürgen. 1992. "Further Reflections on the Public Sphere." In Habermas and the Public Sphere, edited by Craig J. Calhoun, 421-461. Cambridge, MA: MIT Press.

Habermas, Jürgen. 2006. "Political Communication in Media Society: Does Democracy Still Enjoy an Epistemic Dimension? The Impact of Normative Theory on Empirical Research." Communication Theory 16 (4): 411-426. https://doi.org/10.1111/j.1468-2885.2006.00280.x.

Habermas, Jürgen. 2020. "Year 30: Germany's Second Chance." Eurozine, October 30, 2020. https://www.eurozine.com/year-30-germanys-second-chance/.

Harris, Michael H. 1986. "State, Class, and Cultural Reproduction: Toward a Theory of Library Service in the United States." Advances in Librarianship 14 (1): 211-253.

Heller, Agnes. 1991. "The Concept of the Political Revisited." In Political Theory Today, edited by David Held, 330-343. Stanford, CA: Stanford University Press.

Hjørland, Birger. 2005. "Empiricism, Rationalism and Positivism in Library and Information Science." Journal of Documentation 61 (1): 130-155. https://doi.org/10.1108/00220410510578050.

Hohendahl, Peter Uwe. 1979. "Critical Theory, Public Sphere and Culture. Jürgen Habermas and His Critics." New German Critique, no. 16 (Winter): 89-118. https://doi.org/10.2307/487878.

Hove, Thomas. 2009. "The Filter, the Alarm System, and the Sounding Board: Critical and Warning Functions of the Public Sphere." Communication \& Critical/Cultural Studies 6 (1): 19-38. https://doi.org/10.1080/14791420802632095.

Huysmans, Frank, and Marjolein Oomes. 2013. "Measuring the Public Library's Societal 
Value: A Methodological Research Program." IFLA Journal 39 (2): 168-177. https://doi.org/10.1177/0340035213486412.

Ingraham, Chris. 2015. "Libraries and Their Publics: Rhetorics of the Public Library." Rhetoric Review 34 (2): 147-163. doi.org/10.1080/07350198.2015.1008915. Johnson, Catherine A. 2015. "Social Capital and Library and Information Science Research: Definitional Chaos or Coherent Research Enterprise?" Information Research 20 (4): 35-49. http://informationr.net/ir/204/paper690.html\#.X_rrU1hOnX4.

Johnson, Pauline. 2001. "Habermas's Search for the Public Sphere." European Journal of Social Theory 4 (2): 215-236. https://doi.org/10.1177/136843101004002005. Kajberg, Leif. 2013. "Re-Examining the Values of the Public Library in Times of Uncertainty and Hardship." Bibliothek Forschung Und Praxis 37 (3): 293-305. https://doi.org/10.1515/bfp-2013-0053.

Larsen, Håkon. 2021. "The Public Sphere and Habermas: Reflections on the Current State of Theory in Public Library Research." Journal of Documentation 77 (1): 251-58. https://doi.org/10.1108/JD-05-2020-0075.

Lunt, Peter, and Sonia Livingstone. 2013. "Media Studies' Fascination with the Concept of the Public Sphere: Critical Reflections and Emerging Debates." Media, Culture \& Society 35 (1): 87-96. https://doi.org/10.1177/0163443712464562.

Lyon, David. 1986. "From 'Post-Industrialism' to 'Information Society': A New Social Transformation?" Sociology 20 (4): 577-588.

McCook, Kathleen de la Peña. 2004. Introduction to Public Librarianship. New York: Neal-Schuman.

Messer-Kruse, Timothy. 2019. "How Google Scrambled the Academic Mind." Chronicle of Higher Education, May 29. https://www.chronicle.com/article/how-googlescrambled-the-academic-mind/.

Miller, Vincent J. 2012. "When Mediating Structures Change." In When the Magisterium Intervenes, edited by Richard R. Gaillardetz, 154-174. Collegeville, MN: Liturgical Press.

Olmstead, Gracy. 2019. "The Women's March Has Always Been Divisive. Here's How We Can Fix That." Washington Post, January 19, 2019. https://www.washingtonpost.com/outlook/2019/01/19/womens-march-hasalways-been-divisive-heres-how-we-can-fix-that/.

Peters, John Durham. 1987. "The Control of Information." Critical Review: A Journal of Politics and Society 1 (4): 5-23.

Peters, John Durham. 1988. "Information: Notes Toward a Critical History." Journal of Communication Inquiry 12 (2): 9-23.

Peters, John Durham. 1993. "Distrust of Representation: Habermas on the Public Sphere." Media, Culture \& Society, 15 (4): 541-571. https://doi.org/10.1177/016344393015004003.

Randeria, Shalini, and Timothy Snyder. 2020. "A Trumpian Blip or a Fundamental Flaw in American Democracy." Eurozine, November 25, 2020. https://www.eurozine.com/democracy-in-question/.

Rasch, Miriam. 2020. "Friction and the Aesthetics of the Smooth." Eurozine, May 11, 2020. https://www.eurozine.com/friction-and-the-aesthetics-of-the-smooth/. 
Rosen, Jay. 1992. "Playing the Primary Chords." Harper's Magazine (March): 22-26.

Ryan, Mary P. 1998. "Gender and Public Access: Women's Politics in Nineteenth-Century America." In Feminism, the Public and the Private, edited Joan B. Landes, 195222. New York: Oxford University Press.

Schudson, Michael. 1994. "The Public Sphere and Its Problems: Bringing the State (Back) In." Notre Dame Journal of Law, Ethics \& Public Policy 8 (2): 529-46.

Shore, Marci. 2017. The Ukrainian Night: An Intimate History of Revolution. New Haven, CT: Yale University Press.

Slack, Jennifer Daryl. 1984. "Information Revolution as Ideology." Media, Culture \& Society 6 (3): 247-256.

Söderholm, Jonas, and Jan Nolin. 2015. "Collections Redux: The Public Library as a Place of Community Borrowing." Library Quarterly 85 (3): 244-260. https://doi.org/10.1086/681608.

Stolle, Dietlind. 2007. "Social Capital." In The Oxford Handbook of Political Behavior, edited by Russell J. Dalton and Hans-Dieter Klingerman, 655-674. New York: Oxford University Press.

Stone, Lynda. 2011. "Philosophy of Education." In The Handbook of Research in the Social Foundations of Education, edited by Steven E. Tozer, Bernardo P. Gallegos, and Annette M. Henry, 61-73. New York: Routledge.

Taylor, Charles. 1993. "Modernity and the Rise of the Public Sphere." In The Tanner Lectures on Human Values, Vol. 14, edited by Grethe B. Peterson, 204-260. Salt Lake City: University of Utah Press.

Vårheim, Andreas. 2007. "Social Capital and Public Libraries: The Need for Research." Library \& Information Science Research 29 (3): 416-28. https://doi.org/10.1016/j.lisr.2007.04.009.

Vårheim, Andreas. 2008. "Theoretical Approaches on Public Libraries as Places Creating Social Capital." IFLA Conference Proceedings, November, 1-13. http://archive.ifla.org/IV/ifla74/papers/091-Varheim-en.pdf.

Vårheim, Andreas, Roswitha Skare, and Noah Lenstra. 2019. "Examining Libraries as Public Sphere Institutions: Mapping Questions, Methods, Theories, Findings, and Research Gaps." Library \& Information Science Research 41 (2): 93-101. https://doi.org/10.1016/j.lisr.2019.04.001.

Walker, Jack L. 1970. "Normative Consequences of 'Democratic' Theory." In Frontiers of Democratic Theory, edited by Henry S. Kariel, 227-247. New York: Random House.

Warren, Mark. E. 1995. "The Self in Discursive Democracy." In The Cambridge Companion to Habermas, edited by Stephen K. White, 167-200. Cambridge, UK: Cambridge University Press.

Warren, Mark E. 1999. "What is Political?" Journal of Theoretical Politics 11 (2): 207-31. https://doi.org/10.1177/0951692899011002004.

Webster, Frank. 2006. Theories of the Information Society, 3rd ed. New York: Routledge.

Wessler, Hartmut. 2018. Habermas and the Media. Medford, MA: Polity.

Widdersheim, Michael M. 2015. "Governance, Legitimation, Commons: A Public Sphere 
Framework and Research Agenda for the Public Library Sector." Libri:

International Journal of Libraries \& Information Services 65 (4): 237-245. https://doi.org/10.1515/libri-2015-0043.

Widdersheim, Michael M. 2017. "Late, Lost, or Renewed? A Search for the Public Sphere in Public Libraries." Information Research 22 (1): 1-18.

http://informationr.net/ir/22-1/colis/colis1644.html.

Widdersheim, Michael M., and Masanori Koizumi. 2015. "Signal Architectures of US Public Libraries: Resolving Legitimacy Between Public and Private Spheres."

Proceedings of the Association for Information Science and Technology 52 (1): 113. https://onlinelibrary.wiley.com/doi/full/10.1002/pra2.2015.145052010025.

Widdersheim, Michael M., and Masanori Koizumi. 2016. "Conceptual Modelling of the Public Sphere in Public Libraries." Journal of Documentation 72 (3): 591-610. https://doi.org/10.1108/JD-06-2015-0079.

Widdersheim, Michael M., and Masanori Koizumi. 2017. "Methodological Frameworks for Developing a Model of the Public Sphere in Public Libraries." Information Research 22 (1): 1-9. http://informationr.net/ir/22-1/colis/colis1643.html.

Widdersheim, Michael M., and Masanori Koizumi. 2020. "Editorial." Journal of Documentation 76 (3): 617-623. https://doi.org/10.1108/JD-09-2019-0170.

Wiegand, Wayne A. 1999. "The Structure of Librarianship: Essay on an Information Profession." Canadian Journal of Information and Library Science 24 (1): 17-37.

Wiegand, Wayne A. 2015. Part of Our Lives: A People's History of the American Public Library. New York: Oxford University Press.

Wilentz, Sean. 2005. The Rise of American Democracy: Jefferson to Lincoln. New York: Norton.

Wilson, Hugh T. 1985. Political Management: Redefining the Public Sphere. New York: Walter de Gruyter.

Wingo, G. Max. 1974. Philosophies of Education: An Introduction. Lexington, MA: Heath.

Wolin, Sheldon. S. 1996. "Fugitive Democracy." In Democracy and Difference: Contesting the Boundaries of the Political, edited by Seyla Benhabib, 31-45. Princeton, NJ: Princeton University Press.

Zuboff, Shoshana. 2016. "The Secrets of Surveillance Capitalism." Frankfurter Allgemeine Zeitung, May 3, 2016.

https://www.faz.net/aktuell/feuilleton/debatten/the-digital-debate/shoshanazuboff-secrets-of-surveillance-capitalism-14103616.html. 